\title{
A Lab-Made Wound Maker for Analysis of Cell Migration in a 96-Well Plate
}

\author{
Tae Bok Lee ${ }^{1}$, Hwa Ryoung Kim², Seo Young Park ${ }^{3}$ \\ ${ }^{1}$ Confocal Core Facility, Center for Medical Innovation, Seoul National University Hospital, Seoul, Korea \\ ${ }^{2}$ Department of Biomedical Engineering, Seoul National University Hospital, Seoul, Korea \\ ${ }^{3}$ Department of Research and Experiments, Center for Medical Innovation, Seoul National University Hospital, Seoul, Korea
}

\section{세포 이동능력 분석을 위한 96-Well Plate 전용 Lab-Made Wound Maker}

이태복 ${ }^{1}$, 김화룡 ${ }^{2}$, 박서영 ${ }^{3}$

${ }^{1}$ 서울대학교병원 의학연구혁신센터 공초점현미경실, ${ }^{2}$ 서울대학교병원 의공학과, ${ }^{3}$ 서울대학교병원 의학연구혁신센터 연구실험부

\section{ARTICLE INFO}

Received January 3, 2020

Revised February 7, 2020

Accepted February 9, 2020

\section{Key words}

Cell migration

Recovering

Scratching

Synchronized

Wound healing

\begin{abstract}
Cell migration is a central process for recovering from wounds triggered by physical distress besides embryogenesis and cancer metastasis. Wound healing assay is widely used as a fundamental research technique for investigation of two-dimensional cell migration in vitro. The most common approach for imitating physical wound in vitro is mechanical scratching on the surface of the confluent monolayer by using sharp materials. The iron metal pin with a suspension spring for fine adjustment of the orthogonal contact surface between the scratching point and the individual bottom of multi-well plate with planar curvatures were adopted for the creative invention of a 96-well plate wound maker. While classic tips drew diverse and zigzag scratching patterns on the confluent monolayer, our wound maker displayed synchronized linear wounds in the middle of each well of a 96-well plate that was seeded with several cell lines. Given that several types of multi-well plates commercially available are compatible with our lab-made wound maker for creating uniform scratches on the confluent monolayer for the collective cell migration in wound healing assay, it is certain that the application of this wound maker to the real-time wound healing assay in high content screening (HCS) is superior than utilization of typical polypropylene pipette tips.
\end{abstract}

Copyright ${ }^{\circledR} 2020$ The Korean Society for Clinical Laboratory Science. All rights reserved.

\section{INTRODUCTION}

The epithelial cells as a frontline defense mechanism cover the outer surfaces of skin, inner surface of internal organs and blood vessels throughout the body in order to protect the host in case various accidents

\footnotetext{
* Corresponding author: Seo Young Park

Department of Research and Experiments, Center for Medical Innovation, Seoul

National University Hospital, 71 Daehak-ro, Jongno-gu, Seoul 03082, Korea

E-mail:psy0305@snuh.org

* ORCID: https://orcid.org/0000-0003-3953-1653
}

occur caused by chemicals, heat, UV radiation, microorganisms and physical injuries. When this protective tissue is damaged, replacement by newly generated tissue called "wound healing" is quickly processed to restore the defense function [1]. The wound healing assay is a fundamental research technique for investigation of two-dimensional cell migration in vitro. Fibroblasts are crucially involved in the event of normal wound healing as a key modulator by breaking down the fibrin clots, fostering ex- 
tracellular matrix (ECM) and building collagen structures which support surrounding cells for effective wound healing [2]. Cell migration is the common event for recovering from the wound triggered by physical distress and that has been analyzed for a score of years by scratching the cell layer with simple experimental tips varying from 10 to $100 \mu \mathrm{L}$ in size depending on the severity of aimed wounds which mimics physical scratches. Nowadays, more often the cell migration analysis is experimentally applied not only to wound healing, mucosal repairing and epithelial-mesenchymaltransitions under normal development but also embryogenesis, neurogenesis, angiogenesis and in vitro cancer cell invasion [3]. Previously, phagokinetic track assay for single cell migration, and Boyden, Zigmond and Dunn chambers for chemoattractant migration assay have been widely used for in vitro studies of null cell migration without wounding recovery process $[4,5]$. On the other hand, many studies are focusing on wound healing process wherein the consequential active movement of cell fronts towards empty space, which is scraped out of confluent monolayer by sharp materials imitating physical injuries, vividly observed [6]. Moreover, the living cells secrete defense molecules such as antimicrobial peptides (AMPs) and ECM proteins for anti-inflammation and fast recovery from wound [7, 8]. Given that quantifying analysis of cell migration induced by physical scratches duly imitates the actual wound healing process, a metallic wound maker with firm hardness for accurate linearity of scratches and sustainable tension spring for pressure balance given to each single well in the multi-well plate should be in consideration for experimental reproducibility of wound scratches and image data quantification compared to manual scratches with polypropylene pipette tips which demonstrate diverse, nonlinear and irregular wound patterns. In this article, we introduce a 96-channel mechanical wound maker mainly designed for CellCarrier-96 Ultra (PerkinElmer, Germany) microplate and also compatible to a variety of com- mercially available multi-well plates, and demonstrate its spontaneous performance with live cell imaging evaluation by high content screening (HCS) machine.

\section{MATERIALS AND METHODS}

1. Cell culture and High content screening (HCS) analysis

Fibroblast, HCC827, HEK293T, U8MG and HeLa cells were cultured in Dulbecco's Modified Eagle's Medium (DMEM, Welgene, Korea) supplemented with 10\% Fetal Bovine Serum (FBS, Gibco, USA) and $1 \times$ PenicillinStreptomycin antibiotics (Welgene). For multi-well culture, cells were dispensed into a 96 well plate (CellCarrier-96 Ultra, PerkinElmer, Germany) or (Cat\# 30096, SPL Life Sciences, Korea) according to the recommended seeding density $\left(0.01 \times 10^{6}\right)$. The plate was incubated at $37^{\circ} \mathrm{C}, 5 \% \mathrm{CO}_{2}$ for two days consecutively. Wound healing ability was assessed by cell migration analysis of HCS (Operetta CLS, PerkinElmer) from the wounded edge to empty area. Cells were imaged using $\mathrm{z}$-stack function to find the best focus area and each well was analyzed and showed with the multi-field stitching image in addition to bar graphs combined with merged realistic plate images. Cell count and tracking based on plate images were analyzed using digital phase contrast (DPC).

\section{Layout and experimental design of lab-made wound maker}

Pins with a diameter of $0.9 \mathrm{~mm}$ were produced by assembling the upper and lower part with suspension spring for fine adjustment between individual pin's height and bottom surface of multi-well plate. The 96 pins were then planted into the transparent acrylic plate $(125 \times 90 \times 16 \mathrm{~mm})$ as per the dimensions of 96-well plate described at the insert sheet provided by commercially available multi-well plates. Guide rails were designed for smooth, straight and linear movement of wound maker along the both up and down sides of the plate. Plate holder was simply made of black 
acrylic plate for fixing the multi-well plate by attaching several bars surrounded tightly without interspace (Figure 1).

\section{Cell labeling for live imaging and making wounds}

Fibroblast, HEK293T, U87MG and HeLa cells were seeded into a 96 well plate and after 48 hours incubation, cells were labeled with Calcein AM; cellpermeant dye (C1430, Thermo, USA) for 30 minutes. The plate and each well was rinsed twice with $1 \times$ Phosphate buffered saline (PBS) and added with pre-warmed cell culture media. In order to give consistent and homogenous wounds to each 96 wells, the plate was fixed on the plate holder and covered by the lab-made wound maker. By pressing the acrylic plate with moderate force carefully slid the wound maker along the guide rail and plate holder to the end of the well. Each wound was confirmed by naked eyes using widefield microscope (IX50, Olympus, Japan) beforehand and imaged using confocal laser scanning microscope (TCS SP8, Leica, Germany).

\section{Sterilization of wound making pins}

Wound making pins were pulled out of the transparent acrylic plate by tightly holding each pin with sterilized pliers and secured in the stainless steel cotton cylinder for autoclave at $121^{\circ} \mathrm{C}$ for 15 minutes. After which, pins were subjected to dehumidification under dry oven, overnight. In biosafety cabinet (BSC), each pin was planted onto the transparent acrylic plate using sterilized pliers. Acrylic plates were kept in BSC and regularly sanitized using 70\% ethanol, UV irradiation and contamination prevent solution; Bioguard-S (\#1010-1000, Biowest, MO, USA).
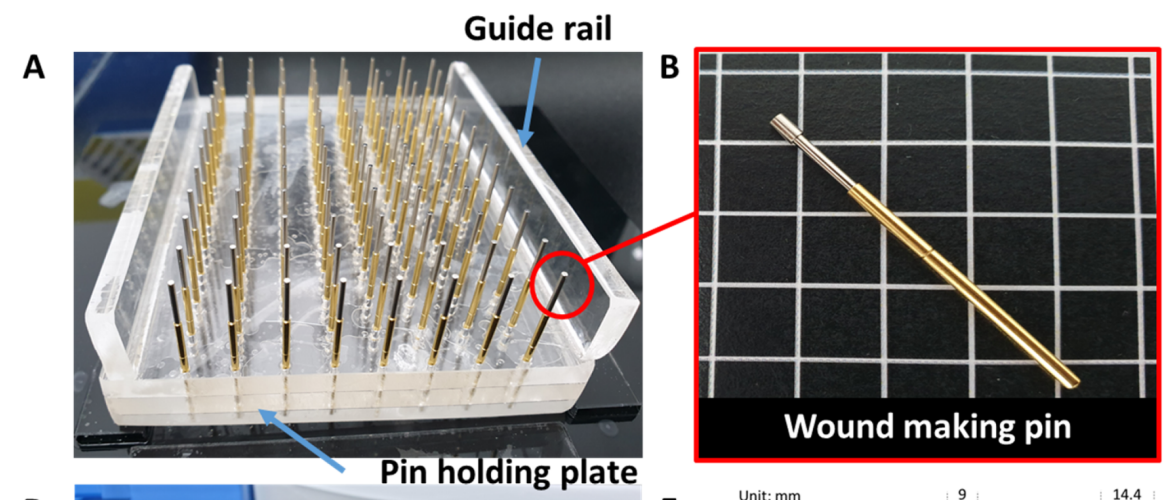

E

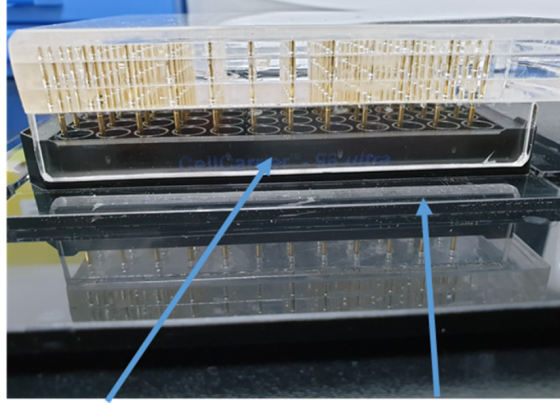

96-well plate
Plate holder

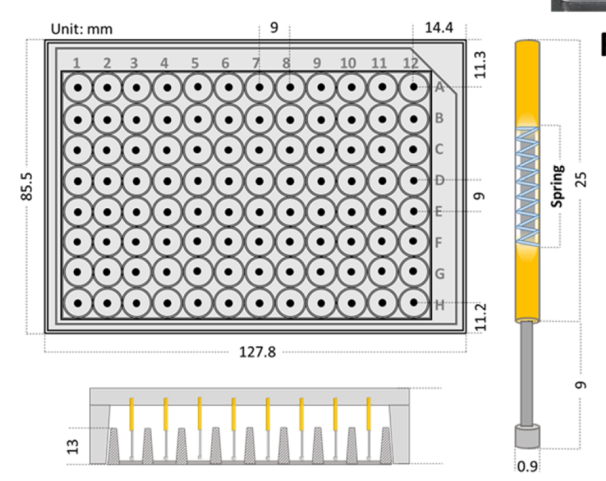

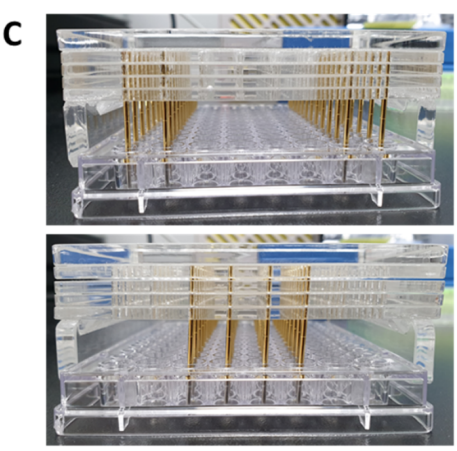

$\mathbf{F}$

Figure 1. Lab-made mechanical wound maker. (A) Lab-made mechanical wound maker composed of 96 spring pins planted on the transparent triple stacked acrylic plates and guide rail for prevention of scratching deviation while moving on the surface of a multi-well plate. (B) Close-up image of wound making pin. (C) Rearrangement of wound making pins in $A, B, G, H$ rows and center integrated type for diverse application in wound healing assay. (D) An image of ready for making mechanical uniform wounds on a 96-well plate which is installed on the plate holder composed of opaque acrylic plate with four-sided panel. (E) An approximately calculated measures of 96-well plate layout for commercially available common plates and scratching spring pin. (F) A section plan describing perpendicular movement of iron metal pin with suspension spring along the well bottom of the plate. 


\section{RESULTS}

1. Comparison of wound modality scratched by

lab-made wound maker and classic tips

Confluence of fibroblast cells were evenly 90 100\% in a 96-well plate in control. A wound maker simultaneously formed regular linear scratches in the middle of each well of the 96-well plate where fibroblast cells were fully seeded and labeled with green fluorescence. On the other hand, commercially available classic tips showed irregular and broad wounds left in the multiwell plate (Figure $2 \mathrm{~A}$ ). In the realistic view of multi-well plate under magnification, details of cells and patterns of scratches were analyzed. Compared to the wound maker, scratching patterns made by classic tips are diverse, complicated and somewhat wider than wound maker (Figure 2B). The scratched area of each single well was quantitatively analyzed and the results were represented as an open area. The open space created by wound maker was mostly monotonous compared to the diverse wounds scratched by classic tips. Similar results were also represented in cell area and confluence since open area, cell area and confluence are arithmetically all connected in the confined well in size. Nevertheless, a notable single deviation was observed in both cell area and confluence in the wounds made by classic tips (Figure 2C).

\section{Superficial artifact on the surface of coated and non-coated plate}

Fibroblast cells were seeded on the tissue-culture (TC) treated cyclic olefin copolymer (COC) bottom multi-well plate in order to investigate surficial scratching artifact consequently triggered by lab-made wound maker. As shown in Figure 3A, no significant differences were observed in the light of digital phase contrast (DPC) images both of classic tip $(100 \mu \mathrm{L})$ and wound making pin. Interestingly, cell segments were more obvious on the scratched region of classic tip (100 $\mu \mathrm{L})$ than wound making pin. On the other hand, bright
A
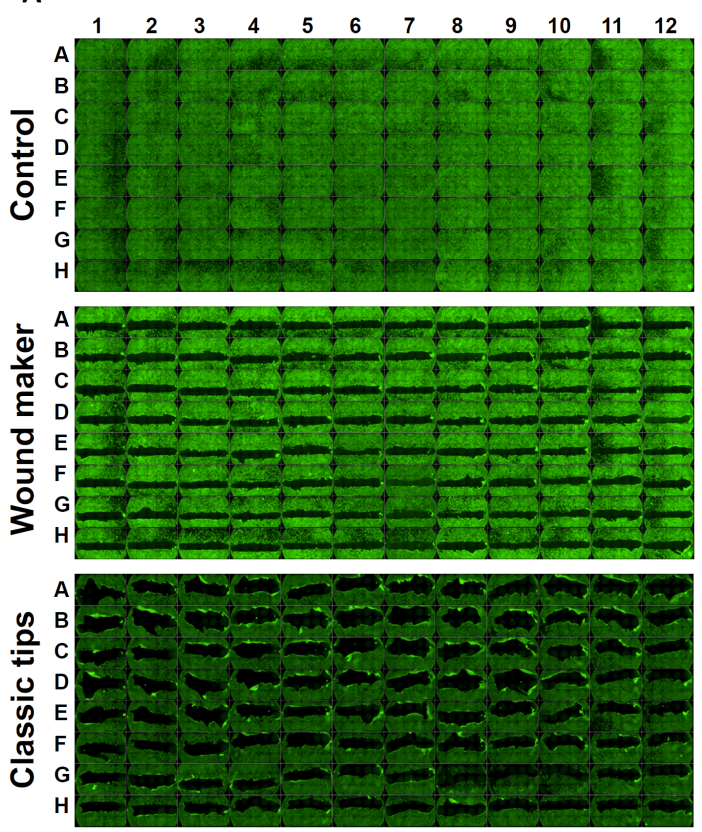

B
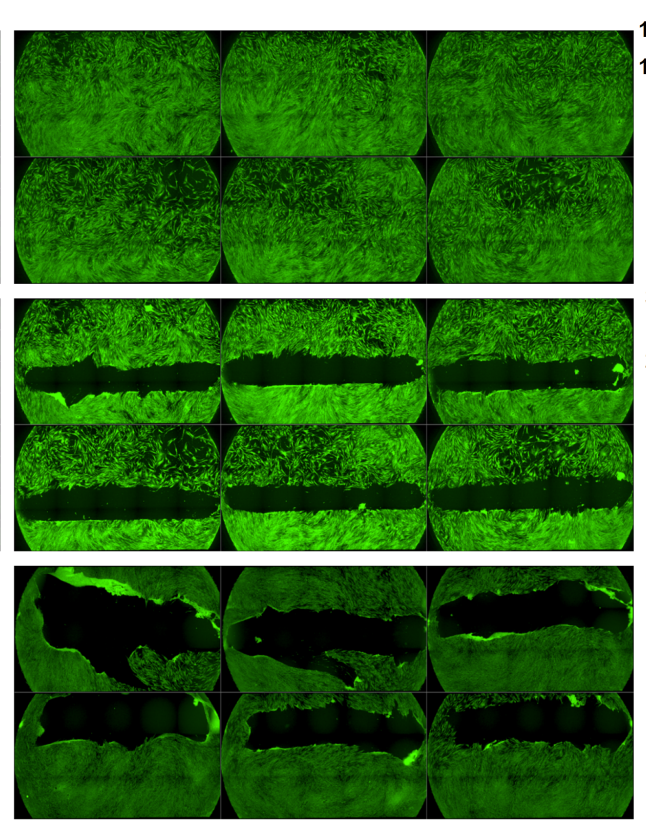

C
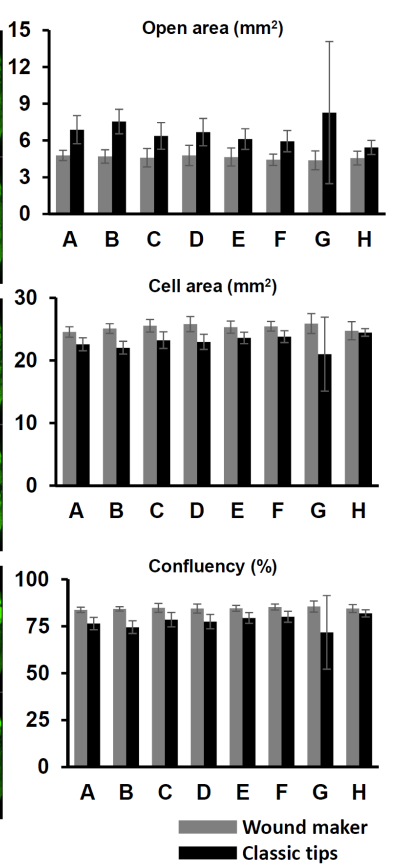

Figure 2. A realistic plate view with magnified well images before and after making in vitro wounds. (A) Realistic overview images of confluent fibroblast monolayer labeled with calcein AM colored green on a 96-well plate before and after making in vitro mechanical wounds by lab-made wound maker or commercially purchased polypropylene pipette tips. (B) Magnification of selected well images. (C) Quantitative data analysis based on open area which represents scratched region of each row. The average measurements of cell area and confluence in the twelve consecutive wells after making wounds are quantitatively presented. 
A

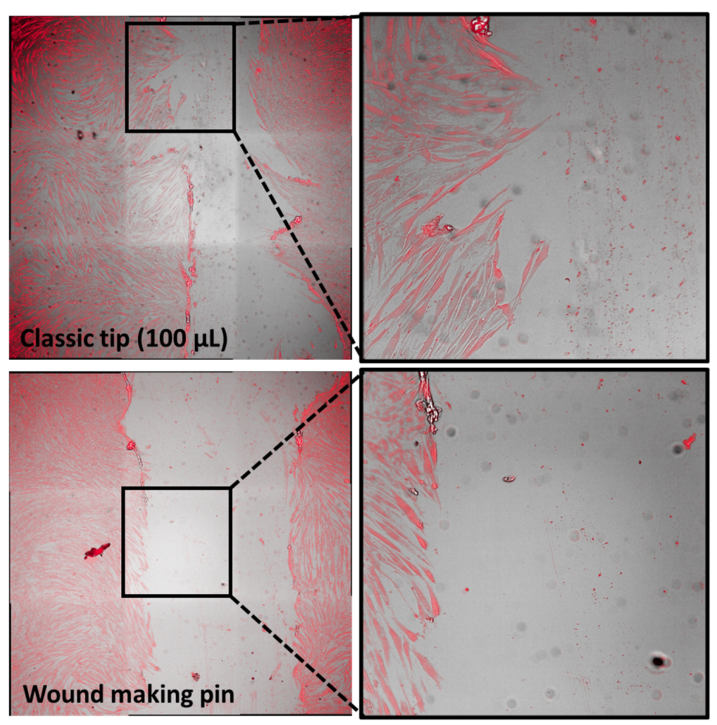

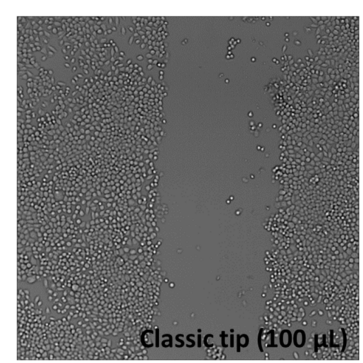

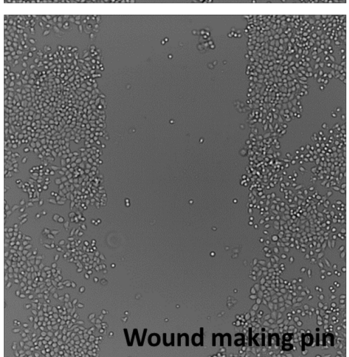

Figure 3. Comparison of scratching artifact on the surface of multi-well plate. (A) Seamless stitching tile scan images of digital phase contrast (DPC) of fibroblast on the tissue-culture (TC) treated cyclic olefin copolymer (COC) material after making physical wounds with classic tip $(100 \mu \mathrm{L})$ and wound making pin. (B) Bright field (BF) images of HCC 827 cells after scratching the surface of the polystyrene multi-well plate with classic tip $(100 \mu \mathrm{L})$ and wound making pin.
A

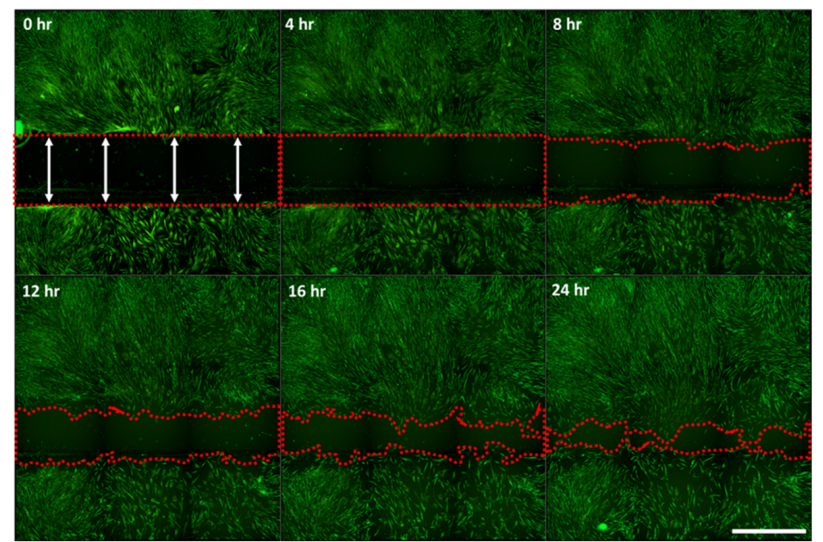

B

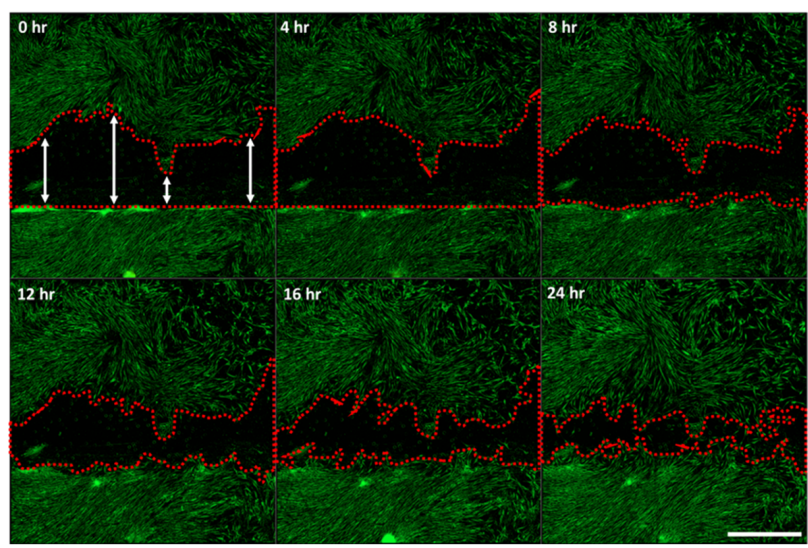

Figure 4. Live cell imaging of in vitro wound healing process. Real-time fluorescent images captured by high content screening (HCS) machine (Operetta CLS, PerkinElmer) for 24 hours after making wounds on the confluent fibroblast monolayer. (A) Live cell images captured at 6 consecutive time points; $0,4,8,12,16$ and 24 hours after giving mechanical wound with lab-made wound maker. (B) Live cell images of polypropylene pipette tip. Scale bar, $1 \mathrm{~mm}$.

field (BF) images of HCC 827 cells on the polystyrene multi-well plate showed clear scratches on the surface besides several wandering cells detached out of original settlement and there was no significant dissimilar between classic tip $(100 \mu \mathrm{L})$ and wound making pin (Figure 3B).

\section{Live cell imaging of in-vitro wound healing}

Regular and linear wounds created by the wound maker showed stable and all-around recovery from the parallel edges of wounds towards open area. On the other hand, irregular and ripped scratches by the polypropylene pipette tip demonstrated asymmetric and inconsistent recovery from the oblique and distorted edges of wounds towards open area with various patterns in the live cell imaging (Figure 4).

4. Precise and accurate mechanical wounds regardless of cells types compared to polypropylene pipette tips

To see whether a lab-made wound maker shows similar results; synchronized, linear and precise pattern of scratching wounds, on the different cell type with 
A
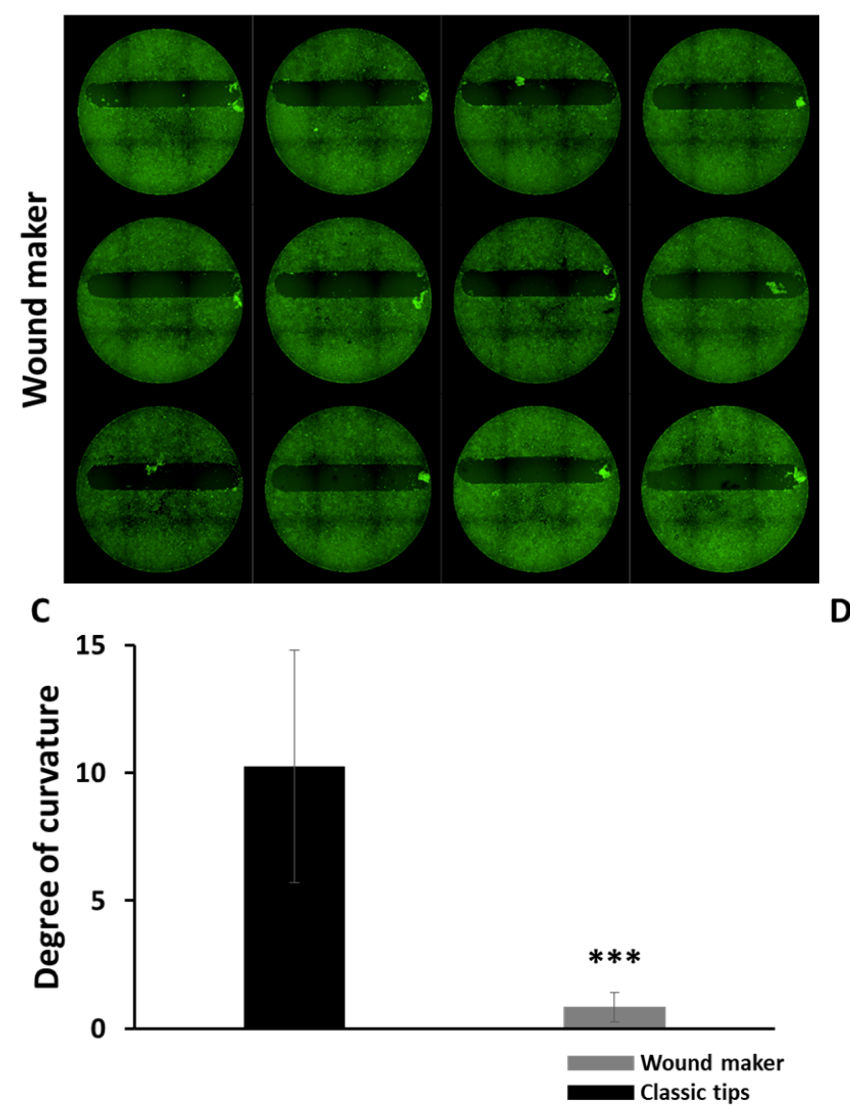

B
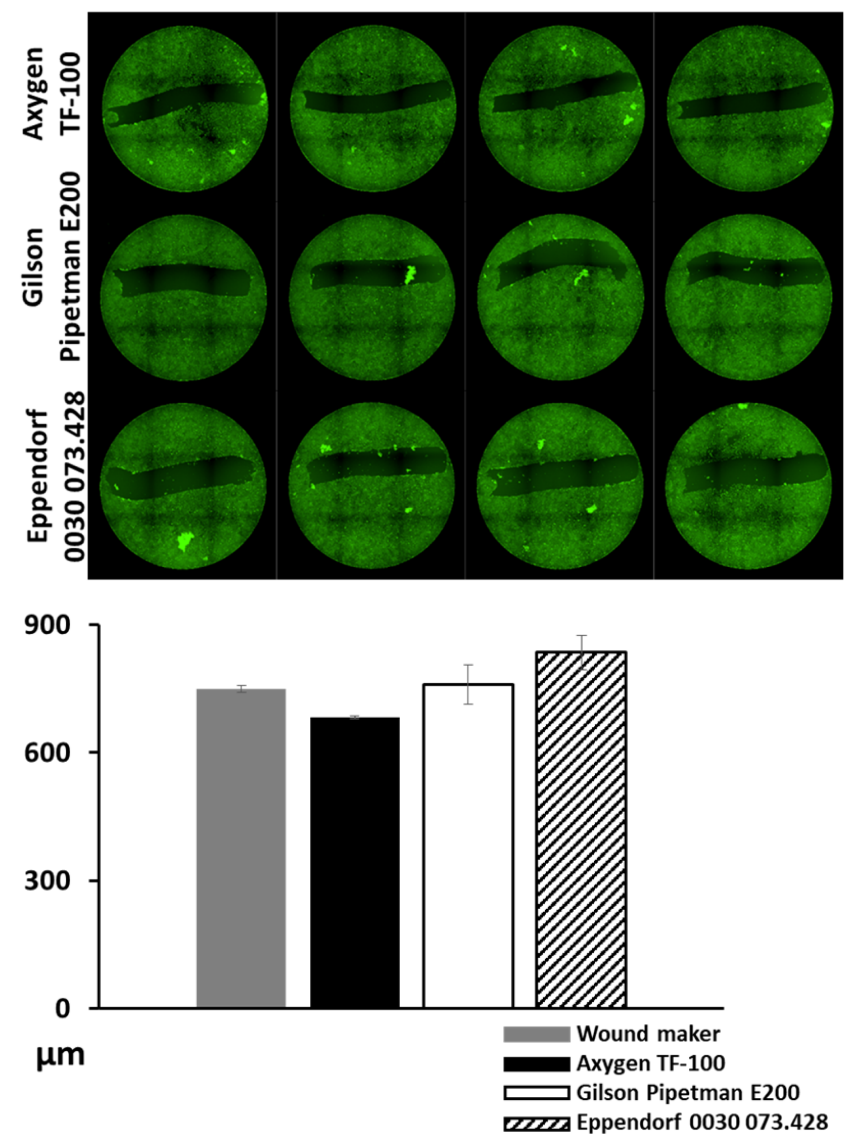

$\mathbf{E}$
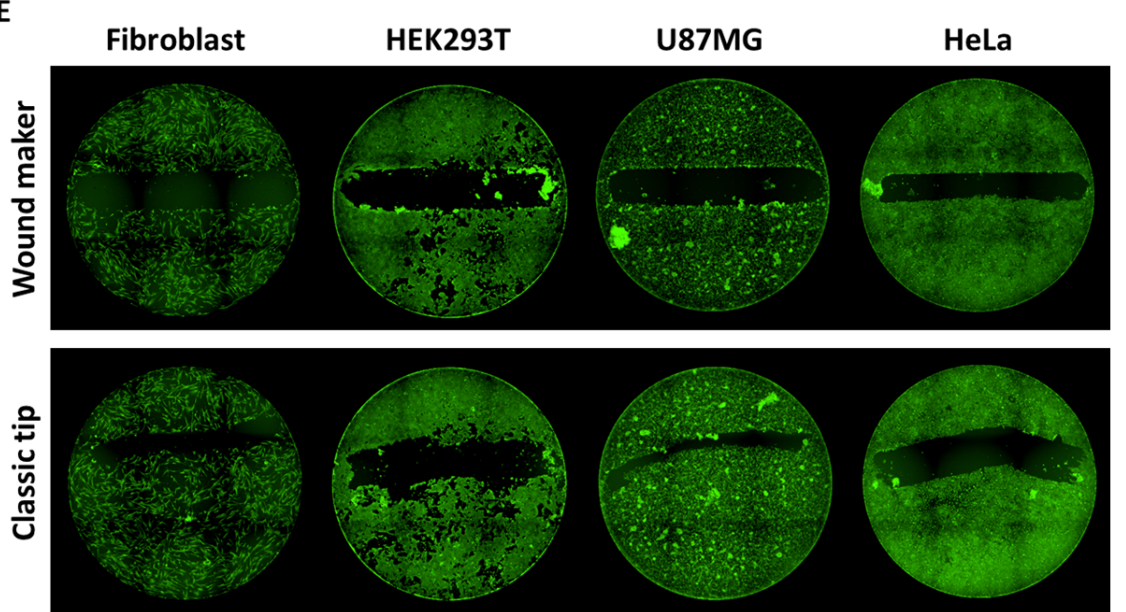

Figure 5. Diverse scratching modalities imparted by individual characteristics of polypropylene pipette tips and cell types. (A) Synchronized mechanical wounds imparted by lab-made wound maker on the multi-well plate with confluent monolayer of HeLa cells. (B) Uneven and irregular scratches made by each commercially available polypropylene pipette tip; Axygen TF-100, Gilson Pipetman E200 and Eppendorf 0030 073.428. (C) Quantification analysis of open area linearity based on scratching curvature and angle thereof. (D) Wound widths of four different conditions: wound maker, Axygen TF-100, Gilson Pipetman E200 and Eppendorf 0030 073.428. (E) Scratching modalities of lab-made wound maker and polypropylene pipette tip on the different cell lines: fibroblast, HEK293T, U8MG and HeLa cells. Data are expressed as the mean \pm SD of sextuplicate determination. ${ }^{* *} P<0.001$. 
higher confluence, multi-well plates were filled with HeLa cells followed by manual scratches with commercially purchased polypropylene pipette tips or semi-automatic mechanical scratches using the labmade wound maker. As shown in Figure 5A and B, each pipette tip used for $100 \mu \mathrm{L}$ pipetting from different manufacturers demonstrates diverse scratching pattern and width of wounds compared to uniform wounds created by the lab-made wound maker. Wound linearity was calculated by measuring a degree of curvature of open area generated by mechanical scratching with lab-made wound maker or manual scratching with polypropylene pipette tips. Indeed, the lab-made wound maker presented synchronized horizontal linear scratches closed to "0" degree. On the other hand, manual scratches showed lopsided curved patterns with various bend angles much higher than the one presented by lab-made wound maker (Figure 5C). There was no significant difference in wound width among lab-made wound maker and several polypropylene pipette tips; however, the typical width created by each scratching material differs from 700 $800 \mu \mathrm{m}$ depending on the thickness of endpoint of each material (Figure 5D). Different cell lines were adopted to see whether the lab-made wound maker demonstrates synchronized linear scratching results alike. As shown in Figure 5E, the lab-made wound maker produced uniform wounds on the diverse confluent monolayers formed by four different cell types: fibroblast, HEK293T, U87MG and HeLa, compared to the irregular and nonlinear wounds made by manual scratches.

\section{DISCUSSION}

The predicaments caused by unsynchronized diverse wounds which are commonly observed in vitro wound scratch and healing experiments in a multi-well plate where all scratches are subjected to homogeneously linear pattern for unbiased and impartial assessment of real time wound recovery drew our attention to devising a simple lab-made wound maker. Different and various wounds in shape and size in one set of collective cell migration experiment for wound repair or cancer metastasis may lead to misconception of data analysis when it comes to the evaluation of wound recovery rate based on different given condition [9-11]. In our previous studies, making uniform in vitro wounds on the monolayer with same degree of cell confluence by scratching the surface using commercially available polypropylene pipette tips were hard in the aspect of accuracy and reproducibility [12, 13]. By adopting uniform pins commercially available made up of inner suspension spring and iron metal frame combined with a stainless steel endpoint, facilitated producing a 96-well plate wound maker by planting each pin along the column and row on the triple stacked acrylic plates as per the layout of multi-well plate (Figure 1). The classic tips made up of polypropylene, a hydrophobic polymer for ultra-low retention of liquid inside a wall, are mostly flexible and resilient in bending by steady pressure and that characteristic interrupts creating homogeneously synchronized wounds on the monolayer surface due to several factors: physical tremor, individual experience and distraction when consecutively scratching the restricted area in a confined round well less than $1 \mathrm{~cm}$ in diameter. On the other hand, our wound maker synchronously scratches monolayer and form uniform open area regardless of individual differences in experience and physical hindrance since all pins are in one plate and simultaneously move towards same direction under orthogonal even pressure (Figure 2). Purchasing commercially available finished wound scratching products costs researchers relatively high price compared to lab-made wound maker (Table 1). There was another novel approach on wound healing assay through the evaluation of cell migration into the gap created by silicon compartment attached onto the 12 -well plate with confluent cell monolayer which is consequentially followed by the detachment of insert and that generates a clean cell-free space approxi- 
Table 1. Specification and price comparison between lab-made wound maker and commercially available finished products

\begin{tabular}{|c|c|c|c|}
\hline Product & Specification & Price (KRW) & Source \\
\hline Lab-made & $\begin{array}{l}\text { Individual spring pins } \\
\text { Uncoated detachable pins } \\
0.9 \mathrm{~mm} \text { wound } \\
\text { Autoclave and } 70 \% \text { ethanol }\end{array}$ & 100,000 & SNUH BME \\
\hline $\begin{array}{l}\text { AccuWound }^{\circledR} \\
96 \text { scratch tool }^{-1}\end{array}$ & $\begin{array}{c}\text { Teflon }^{\mathrm{TM}} \text { Coating flexible pins } \\
\text { Fixed type (not detachable) } \\
1.2 \mathrm{~mm} \text { wound } \\
70 \% \text { ethanol }\end{array}$ & $9,000,000$ & $\begin{array}{c}\text { ACEA Bio (https://www.aceabio.com/wp-content/uploads/ } \\
\text { accuwound-20181109-v1.5-PRINT.pdf) }\end{array}$ \\
\hline AFIX96FP6W & $\begin{array}{l}\text { Uncoated detachable pins } \\
\text { Diverse selection of pins } \\
(0.23 \sim 1.58 \mathrm{~mm} \text { wounds) } \\
\text { Autoclave and } 70 \% \text { ethanol }\end{array}$ & $20,000,000$ & $\begin{array}{l}\text { V\&P Scientific (http://vp-sci.com/products/pin-tools/ } \\
\text { wounding-pin-tools/wounding-fixtures/afix96fp6w.html) }\end{array}$ \\
\hline $\begin{array}{l}\text { IncuCyte }{ }^{\circledR} \\
\text { WoundMaker }\end{array}$ & $\begin{array}{l}\text { Fixed type (not detachable) } \\
0.7 \sim 0.8 \mathrm{~mm} \text { wound } \\
70 \% \text { ethanol }\end{array}$ & $\begin{array}{l}\text { WoundMaker alone } \\
\text { is not purchasable }\end{array}$ & $\begin{array}{c}\text { Sartorius (https://mww.essenbioscience.com/media/uploads/ } \\
\text { files/8400-0012-D00_-_Migration_Invasion_User_Manual3_ } \\
\text { Protocols.pdf) }\end{array}$ \\
\hline
\end{tabular}

mately $500 \mu \mathrm{m}$ in width as a pseudo-wound without physical scratching [8, 14, 15]. Although the cell-free region called pseudo-wound created by physical barrier does not manifest the tissue injury followed by secretion of subordinate cellular component necessarily related to the wound healing processes, it seems more focused on the collective cell migration in cancer metastasis, inflammation and angiogenesis where the artificial cell injuries are not involved [16, 17]. Our wound maker is only designed for evaluation of collective cell migration in wound healing process by scratching the monolayer surface on a 96-well plate, simultaneously and synchronously. Furthermore, the individual suspension spring of scratching pins provides a perpendicular flexibility and advisable adoptability to the diverse bumpy thickness and irregular flatness of the individual well found in low-quality multi-well plates. Thus, several multi-well plates universally used for high content screening (HCS) are also acceptable for in vitro real-time wound healing experiment by applying our simplified 96-well wound maker.

\section{요 약}

Cell migration은 embryogenesis 혹은 cancer metastasis 이외에, 물리적 손상에 의한상처의 수복을 위해서 손상된 부위 로 세포가 이동하는 매우 흔하게 관찰되는 현상 중 하나 이다.
Wound healing assay는 in vitro의 이차원 평면상에서 세포 의 이동을 관찰할수 있는 기본적인 연구 기법이다. In vitro상에 서 물리적 손상을 재현하는 가장 손쉬운 접근법으로서, 세포의 confluent monolayer 표면에 날카로운 도구를 이용하여 기계 적인 스크레치를 내는 방법이 사용되고 있다. 완충 스프링이 탑 재된 금속 핀을 96-well plate를 기반으로 하는 wound maker 에 장착하여 multi-well plate 바닥 표면의 고르지 못한 굴곡과 스크레칭 팁 사이에 직각을 이루는 접촉면에서의 미세한 조절이 가능하도록 하였다. 실험용 팁으로 confluent monolayer위 에 스크래치를 내었을 때에는 다양한 지그재그 패턴이 그려진 반면에, 직접 제작한 wound maker에서는 동일한 형태의 선형 wounds가 fibroblast가 seeding된 96-well plate의 각 well 의 중심부에 그려짐을 확인하였다. 상용화 되어있는 몇몇 multi-well plate가 본 실험에서 제작된 wound maker와 호 환되는 것을 고려하여 보았을 때에, 실시간 wound healing을 관찰하는 high content screening (HCS)실험에 있어서의 활 용적인 측면에서 기존의 전형적인 polypropylene 파이펫 팁을 이용한 스크래칭 방법보다 더욱 용이한 방법임을 알 수 있다.

Acknowledgements: None

Conflict of interest: None

Author's information (Position): Lee $\mathrm{TB}^{1}$, M.T.; Kim HR${ }^{2}$, M.E.T.; Park SY , M.T.

\section{REFERENCES}

1. Yeh CJ, Chen CC, Leu YL, Lin MW, Chiu MM, Wang SH. The effects of artocarpin on wound healing: In vitro and in vivo studies. Sci Rep. 2017;7:15599. http://doi.org/10.1038/s41598-017-15876-7 
2. Bainbridge P. Wound healing and the role of fibroblasts. J Wound Care. 2013;22:407-412. http://doi.org/10.12968/jowc.2013.22.8.407

3. Poon PY, Yue PY, Wong RN. A device for performing cell migration/wound healing in a 96-well plate. J Vis Exp. 2017;7:121. http://doi.org/10.3791/55411

4. Irimia D. Microfluidic technologies for temporal perturbations of chemotaxis. Annu Rev Biomed Eng. 2010;12:259-284. http://doi.org/10.1146/annurev-bioeng-070909-105241

5. Nogalski MT, Chan GC, Stevenson EV, Collins-McMillen DK, Yurochko $\mathrm{AD}$. A quantitative evaluation of cell migration by the phagokinetic track motility assay. J Vis Exp. 2012;70:E4165. http://doi.org/10.3791/4165

6. Yue PY, Leung EP, Mak NK, Wong RN. A simplified method for quantifying cell migration/wound healing in 96-well plates. J Biomol Screen. 2010;15:427-433. http://doi.org/ 10.1177/1087057110361772

7. Trepat X, Chen Z, Jacobson K. Cell migration. Compr Physiol. 2012;2:2369-2392. http://doi.org/10.1002/cphy.c110012

8. Cappiello F, Casciaro B, Mangoni ML. A novel in vitro wound healing assay to evaluate cell migration. J Vis Exp. 2018;17:133. http://doi.org/10.3791/56825

9. Grada A, Otero-Vinas M, Prieto-Castrillo F, Obagi Z, Falanga V. Research techniques made simple: analysis of collective cell migration using the wound healing assay. J Invest Dermatol. 2017;137:E11-E16. http://doi.org/10.1016/j.jid.2016.11.020

10. Grimmig R, Babczyk P, Cillemot P, Schmitz KP, Schulze M, Tobiasch E. Development and evaluation of prototype scratch apparatus for wound assays adjustable to different forces and substrates. Appl Sci. 2019;9:4414. http://doi.org/10.3390/ app9204414

11. Friedl P, Gilmour D. Collective cell migration in morphogenesis, regeneration and cancer. Nat Rev Mol Cell Biol. 2009;10:445-457. http://doi.org/10.1038/nrm2720

12. Lee TB, Jun JH. Can hinokitiol kill cancer cells? Alternative therapeutic anticancer agent via autophagy and apoptosis. Korean J Clin Lab Sci. 2019;51:221-234. http://doi.org/10.15324/ kjcls.2019.51.2.221

13. Moon S, Kim W, Kim S, Kim Y, Song Y, Bilousov O, et al. Phosphorylation by NLK inhibits YAP-14-3-3-interactions and induces its nuclear localization. EMBO Rep. 2017;18:61-71. http://doi.org/10.15252/embr.201642683

14. Riahi R, Yang Y, Zhang DD, Wong PK. Advances in wound-healing assays for probing collective cell migration. J Lab Autom. 2012;17:59-65. http://doi.org/10.1177/2211068211426550

15. Hui EE, Bhatia SN. Micromechanical control of cell-cell interactions. Proc Natl Acad Sci U S A. 2007;104:5722-5726. http://doi.org/10.1073/pnas.0608660104

16. Van Horssen R, Ten Hagen TL. Crossing barriers: the new dimension of 2D cell migration assays. J Cell Physiol. 2011; 226:288-290. http://doi.org/10.1002/jcp.22330

17. Cai G, Lian J, Shapiro SS, BeachamDA. Evaluation of endothelial cell migration with a novel in vitro assay system. Methods Cell Sci. 2000;22:107-114. http://doi.org/10.1023/a:1009864613566 